\title{
Problemas fundamentais E estado atual DAS PESQUISAS SOBRE OS ÍNDIOS DO BRASIL
}

\author{
Egon Schaden ${ }^{a}$
}

[297] Antes de entrar no assunto que me foi proposto, peço vênia para algumas rápidas observações preliminares. A primeira é que me parece mais razoável uma palestra de caráter informativo, a título de balanço, com juízos críticos apenas gerais e sem apreciação do valor intrínseco dos diferentes trabalhos deste ou daquele autor, cuja escolha, ademais, procura dar menos visão compreensiva do que extensiva do panorama etnológico do Brasil. Em segundo lugar, abstenho-me de discutir o que se deve entender por problemas fundamentais, uma vez que, a rigor, parece-me, a toda cogitação científica pode advir importância primária ou secundária, de acordo com o grau de desenvolvimento a que tenha chegado a disciplina em apreço, com os rumos teóricos que se lhe queiram imprimir, ou ainda com referência a essa ou aquela orientação de interesses práticos. Como quer que seja, o critério de seleção adotado considera as tendências hoje dominantes nas pesquisas indianistas no Brasil, de um lado, e do outro alguns setores em que os estudos atuais, na medida em que sou capaz de avaliá-los, afiguram-se me em flagrante atraso em confronto com o que se fez em outras terras ou outras épocas. Em terceiro lugar, enfim, desejo explicar que esboçarei em traços rápidos a marcha das investigações destes últimos vinte ou vinte e cinco anos, período que se revela decisivo quanto a progressos e mudanças radicais. Iniciando a exposição do assunto, vejamos logo por quê.

[298] Nos fins do primeiro quarto deste século, iniciou-se, na literatura brasileira, um movimento de renovação que recebeu o nome "modernista". Não somente propugnava novas concepções de arte literária, como também focalizava de preferência temas genuinamente brasileiros ou tidos como tais. A atenção dos escritores se voltava para as peculiaridades da terra e da gente, e o aborígene, se não lhe coube o papel que desempenhara em certa fase do romantismo, veio a ser

a Egon Schaden (1913-1991) foi um importante antropólogo brasileiro, nascido em São Bonifácio, município de imigração alemã de Santa Catarina. Tornou-se professor de Antropologia da USP em 1949, quando Emílio Willems se transferiu para os Estados Unidos. É conhecido, sobretudo, por sua produção sobre a cultura guarani. Em 2013 completaria cem anos. O presente diagnóstico foi elaborado por Schaden para o XXXI Congresso Internacional de Americanistas, ocorrido em São Paulo, entre 23 e 30 de agosto de 1954, posteriormente publicado nos Anais do XXXI Congresso Internacional de Americanistas (Editora Anhembi, 1955, p. 297-311). 
figura obrigatória na poesia e no romance nacionais. Mário de Andrade, Cassiano Ricardo, Plínio Salgado, Raúl Bopp, para citar apenas alguns, passaram a explorar a bibliografia etnográfica - na medida em que lhes era acessível - à cata de assunto literário ou até viajaram, eles mesmos, pelo Brasil afora, para terem o que se poderia chamar de vivência do índio. E, por intermédio dos poetas e romancistas, aos poucos o grande público passou, por sua vez, a interessar-se bastante pelas “coisas brasileiras”, inclusive por assuntos indígenas. Tal circunstância veio ter expressão viva na procura inaudita de livros sobre o Brasil em língua portuguesa, concretizando-se, por exemplo, no lançamento da coleção "Brasiliana”, da Companhia Editora Nacional, de São Paulo, que, abrangendo hoje algumas centenas de volumes, representa um dos acontecimentos mais notáveis da história editorial do país. Em conexão com o fato, formou-se clima propício à tradução, para o vernáculo, das obras clássicas, sobretudo alemãs, de nossa etnologia, como o sejam as de Karl von den Steinen, Fritz Krause, Paul Ehrenreich, Max Schmidt, Wilhelm Schmidt e outras, como para a tradução ou reedição de textos de velhos cronistas, como Anchieta, Nóbrega, Staden, Léry, Thevet, Abbeville e assim por diante.

A divulgação de todos esses textos tornou possível, pela primeira vez, aos estudiosos brasileiros obterem informação bastante exata e completa do estado em que se encontravam as pesquisas relativas ao índio brasileiro. E para que se formasse um grupo de especialistas, munidos do necessário cabedal de conhecimentos teóricos e de método, juntou-se àqueles outros fatores, na década de 1930, em várias cidades brasileiras, com a fundação de cursos universitários com ensino [299] sistemático das disciplinas antropológicas e sociológicas e estímulo para pesquisas, por sua vez incentivadas por meio de recursos financeiros, embora parcos, postos à disposição dos cientistas para a realização de trabalhos de campo, por instituições oficiais e particulares, bem como por alguns capitalistas de boa vontade. E começou a formar-se não somente mercado para as obras que se publicavam ou reeditavam em português - mencionemos ainda as de Roquette-Pinto, Baldus, Colbacchini e Albisetti, Coudreau, Métraux, Ramos, Pinto, em sua maioria insertas na mencionada coleção "Brasiliana" -, mas também o fato, não menos decisivo, da atmosfera favorável à existência de revistas mais ou menos especializadas, em que os antropólogos brasileiros pudessem dar publicidade aos seus trabalhos em sua própria língua. Pioneira nesse sentido foi, em São Paulo, a Revista do Arquivo Municipal, do Departamento de Cultura, a qual seguiu a Revista Sociologia, com "secção etnológica", a cargo de Herbert Baldus, e, posteriormente, a "nova série" da Revista do Museu Paulista, também dirigida por Baldus e quase exclusivamente dedicada a assuntos indígenas, além de, há dois anos, finalmente, 
a Revista de Antropologia, da Universidade de São Paulo, que procura apresentar estudos relativos aos índios brasileiros em um enquadramento mais amplo de exploração antropológica do Brasil.

Entre os fatores responsáveis pelo incremento da etnologia em nosso país nestes últimos dois ou três decênios, quero apontar ainda o terem várias instituições universitárias dos Estados Unidos voltado sua atenção para nossos silvícolas, quer, em primeiro lugar, patrocinando e promovendo trabalhos de antropólogos norte-americanos entre as tribos brasileiras, como os de Wagley, Henry, Watson e outros (alguns deles fazendo suas expedições juntamente com jovens cientistas nacionais), quer, em segundo, incumbindo a um grande etnólogo radicado no Brasil (refiro-me a Curt Nimuendajú) de estudar, de maneira sistemática, determinadas culturas indígenas, especialmente com relação à organização social. Em último lugar, para não alongar demais essa enumeração, lembro o interesse que o Serviço de Proteção aos Índios [30o] principiou a dispensar, há cerca de um decênio, ao conhecimento dos naturais da terra, auxiliando ou promovendo a investigação científica, a fim de, na medida do possível, tirar daí alguma diretriz para a solução de problemas práticos de tutela e governo dos grupos aborígenes em contato com o mundo civilizado.

Tudo isso em conjunto nos autoriza a falar em uma nova era da etnologia brasileira, cujo início se pode marcar por volta de 1930, embora o declínio da anterior corresponda ao início da Primeira Guerra Mundial.

Esperemos que os trabalhos da nova fase venham aos poucos a contar com a participação sistemática, tão profícua outrora, dos especialistas da Europa Central, sobretudo alemães, que foram os que, no século XIX, imprimiram pela primeira vez um cunho verdadeiramente científico à descrição e à interpretação das culturas indígenas do Brasil. Desde já consignamos por isso, com regozijo, as pesquisas empreendidas nesses últimos anos no interior do país por cientistas europeus, como, por exemplo, Franz Caspar, na região do Guaporé, e Alfred Métraux, no Xingu, bem como a recente vinda de Hans Becher com o intuito de trabalhar entre silvícolas do Trombetas. Várias publicações de autores europeus há pouco lançadas - entre elas, o estudo de Haekel sobre a estratificação cultural e o substancioso volume de Zerries sobre questões de mitologia - testemunham que as expectativas de fecunda colaboração internacional sobre base mais ampla não se reduzirão a quimeras.

Desde que se fizeram, há pouco mais de um século, as primeiras tentativas de apresentar em um enquadramento científico os informes relativos aos nossos índios, verificou-se haver inúmeras notas úteis ou mesmo preciosas (em parte 
insubstituíveis) em escritos, não raro redigidos com outros fins, a começar pela chamada certidão de nascimento do Brasil, a carta de Pero Vaz de Caminha. Problema básico é, na situação atual, o arrolamento e o exame crítico dessas fontes, como dos muitos estudos grandes e pequenos, escritos por especialistas, "curiosos" e amadores. Pouco se havia feito até então nesse sentido. Tanto mais convém insistir no passo que [301] se acaba de dar com a publicação da extensa Bibliografia crítica da etnologia brasileira, de Herbert Baldus, a primeira que proporciona visão de conjunto, admirável pela abundante informação dos recursos bibliográficos existentes até fins de 1952. Aos 1.785 títulos aí discutidos outros poderiam ser acrescentados, é claro, e de uns tantos juízos, bem como da maneira de emiti-los, pode-se divergir, mas em todo o caso não é concebível, daqui para o futuro, especialista em etnologia brasileira que não tenha esse livro entre os manuais de consulta obrigatória.

Seria de desejar, a essa altura, instrumento de trabalho complementar àquele: a saber, uma síntese da etnologia brasileira em seu estado atual, com vistas a uma formulação bastante precisa de assuntos e problemas a serem focalizados, de preferência, pelos que pretendam se dedicar à tarefa de levar avante as investigações. $\mathrm{O}$ Handbook of South American Indians, conquanto monumental realização de um grupo de competentes especialistas, só em parte satisfaz àquela necessidade, por fornecer, antes de mais nada, um levantamento do material existente, em vez de aprofundar, em um quadro de conjunto, a apreciação crítica dos elementos e das conclusões. E as tentativas de sistematização mais sumárias, como a de Krickeberg e de Ramos, são hoje inteiramente obsoletas, quer no tocante às fontes que exploram, quer aos resultados a que chegam.

Dentro de certas orientações teóricas, é tido como fundamental o problema de classificação das culturas aborígenes, especialmente com referência à sua distribuição e à situação mútua no ambiente geográfico, como em vista aos fenômenos ecológicos intergrupais. Ao passo que, por exemplo, para o continente africano ou para a América do Norte, parece ter sido possível superar as principais dificuldades que se opunham a uma classificação das culturas no sentido de se caracterizarem áreas distintas com seus respectivos centros de irradiação e dinâmica expansiva, em oposição a zonas fronteiriças ou intermediárias, tem-se a impressão de que o conceito de "área cultural”, elaborado pela teoria etnológica, não é [302] satisfatoriamente aplicável à maior parte do território brasileiro. É o que parecem revelar as falhas, a meu ver insuperáveis, das tentativas feitas. Elas se iniciaram com a de Cooper (esboçada em 1925), abstração feita de divisões etnográficas como a apresentada por Max Schmidt, em 1924, que, aliás, parece não ter tido aceitação. A 
de Cooper e a de Murdock, uma e outra procurando estabelecer áreas culturais na América do Sul, não apenas no Brasil, foram as mais discutidas, tendo a primeira servido de base para a organização do Handbook of South American Indians, editado pela Smithsonian Institution, sob a direção de Steward. A de Murdock, que se liga ao plano da Human Relations Area Files, não pôde até hoje ser experimentada, a não ser de modo sumário e esquemático pelo próprio Murdock e depois por Emílio Willems no pequeno volume Brasil - Período indígena, escrito para o Programa de História da América, por incumbência do Instituto Panamericano de Geografia e História. O sistema de Murdock, considerando divisões políticas modernas e diferenças culturais aborígenes, não pôde levar em conta as áreas geográficas. É, porém, mais pormenorizado do que o de Cooper e de Steward, repartindo as tribos brasileiras em doze áreas culturais, que em parte transcendem as fronteiras do país. Insistindo antes na presença do que na ausência de elementos culturais, deveria em tese conduzir a resultados mais positivos. Entretanto, na prática, o próprio mapa das áreas culturais de Murdock revela como é discutível, para o Brasil, a vantagem de especificações menos sumárias para cada unidade e, talvez mais ainda, como é problemática qualquer tentativa de reduzir o complicadíssimo quadro étnico do Brasil aborígene à singeleza de duas, dez ou mesmo vinte áreas culturais. É significativo que Steward, no esforço de elaboração mais pormenorizada do que ele chamou de "cultural areas of the tropical forests", advirta desde logo não ter conseguido senão chegar a um esquema "frankly hypothetical, sketchy and preliminary" (Handbook of South American Indians, v. 3, p. 883). E compreende-se, sem que haja o perigo de hoje em dia, alguém retomar a ideia do "colluvies gentium" [303] de von Martius. Sabemos que em época pré e pós-colombiana, as migrações de muitas tribos, principalmente das famílias Tupi-Guarani e Karaíb, foram tão numerosas e tão extensas que parece não haver o grau de estática espacial exigido para a aplicação do conceito de área cultural - de modo a se abranger o território de todo o país. Surge, assim, a pergunta capital: qual o princípio, o critério de classificação bastante simples e ao mesmo tempo bastante plástico que permita delimitar as áreas, em um sentido em que elas sejam não artificiais e impostas à realidade, mas impostas pela realidade? Que seja, enfim, critério intrínseco e não extrínseco?

Duvido que cheguemos um dia a resultado satisfatório no estabelecimento de áreas culturais, que permitam investigações sistemáticas e coordenadas das configurações tribais com referência aos ambientes geográficos e a centros de expansão e dominância, áreas ativas e passivas, bem como a outros fenômenos ecológicos intertribais. As bases teóricas das classificações não satisfarão as exigências 
mínimas enquanto não captarem nem definirem o que realmente caracterize uma determinada área cultural do Brasil aborígene em oposição a outra e enquanto as divisas entre uma e outra continuem sendo traçadas de forma tão arbitrária como tem sido feito.

Outro problema fundamental, ligado àquele, o da classificação das línguas aborígenes brasileiras, conseguiu, nestes últimos decênios, ser levado à posição mais satisfatória por sábios incansáveis, como Loukotka, Mason e Nimuendajú. No Brasil - ao contrário do que se registra em outras regiões do mundo -, a correspondência entre a diferenciação linguística e cultural é, embora evidentemente não absoluta, pelo menos tão considerável que a dificuldade de se encontrarem divisões de áreas culturais que sirvam como profícuo instrumento de análise científica é compensada pela possibilidade, que se nos oferece, de em geral nos contentarmos com a classificação linguística. E à medida que progridem - reconheça-se que é lentamente - as pesquisas sobre os caracteres raciais ou físicos dos índios brasileiros, vai se notando que [304] àquela relativa correspondência cultural e linguística se acrescenta a de ordem somática, a tal ponto que - como bem sugeriu Gusinde, no Congresso de Americanistas de 1949 - os especialistas em antropologia física chegarão um dia a desistir de uma rígida divisão dos aborígenes sul-americanos (no caso: brasileiros) em tantas ou quantas raças, preferindo, ao contrário, falar em tipos somáticos tribais ou locais.

De qualquer forma, as classificações raciais até hoje propostas não se fundamentam em dados científicos bastante significativos, nem bastante seguros. Vão passando indiscriminadamente de um autor para outro, sem que se lhes aduzam os argumentos necessários, apenas com uma ou outra modificação que torne um pouco mais complexo o sistema em confronto com o dos antecessores. E se constitui um progresso a aludida comunicação de Gusinde, não menos o fora a atitude de McCrown (Handbook of South American Indians, v. 6, p. 7), ao denunciar a precariedade, por exemplo, da demonstração antropológica em que repousaria a ideia de uma "raça" da Lagoa Santa, hipótese que, uma vez lançada, obteve foros de verdade científica, para passar, sem mais exame crítico, de mão em mão - ou de livro em livro. Enfim, tanto o estudo das raças ameríndias extintas como o das atuais (na medida em que é possível delimitá-las) estão a exigir uma revisão de alto a baixo. O que nos falta - disseram-no com acerto Stewart e Newman (Handbook of South American indians, v. 6, p. 19) - é um Hrdlička, alguém que não se furte ao esforço de uma crítica geral, sobre base comparativa, de todo o acervo existente. Isso quanto ao material fóssil. Para as tribos da atualidade, é preciso que em todos os grupos de aborígenes brasileiros - na medida em que 
as condições demográficas prometam resultados estatisticamente significativos - sejam feitas pesquisas de antropologia física por um grupo de cientistas que, em vez de trabalharem isoladamente, cada um segundo seus pendores pessoais, estejam dispostos a orientar, a conjugar as investigações de acordo com normas técnicas uniformes. Por enquanto, cada instituição [305] brasileira tem sua ficha antropométrica própria: o Museu Nacional, o Instituto de Pesquisas Educacionais, a cadeira de Antropologia da Universidade de São Paulo e assim por diante. Difícil será aproveitar um dia os resultados parciais para a tão necessária síntese preliminar, sem a qual não haverá base sequer para a formulação de problemas novos e mais específicos.

A bibliografia de Comas, de 1948, mostrou bem que as publicações existentes não são poucas; muito ao contrário. O que falta é maior número de trabalhos executados em obediência a algum plano de colaboração sistemática entre instituições e cientistas - deficiência notória, aliás, de quase tudo o que se tem escrito sobre os índios brasileiros, quer do ponto de vista racial, quer do linguístico ou do cultural. Que tal se desse em épocas passadas, compreende-se; que se dê hoje em dia, é pena.

No tocante à elaboração teórica, é antigo desideratum da etnologia brasileira o enquadramento dos dados da pesquisa, quer bibliográfica, quer de campo, em uma discussão de pontos de vista gerais da ciência da cultura. No passado, um autor apenas - Karl von den Steinen - correspondeu plenamente a tal exigência, pela apresentação, inteligente quão sugestiva, dos resultados de sua segunda expedição ao Alto-Xingu. Entre os cientistas contemporâneos interessados no estudo das culturas indígenas brasileiras, tal preocupação passa agora aos poucos a ocupar o lugar que merece. Em sua maioria, anima-os o desejo, mais ou menos pronunciado e vivo, de contribuírem para o aprofundamento, a clarificação e o enriquecimento de diversas perspectivas teóricas da etnologia moderna.

Nesse sentido, destacam-se do conjunto as contribuições de Florestan Fernandes, interessado especialmente na reconstrução dos diferentes aspectos da cultura Tupinambá por meio da análise histórico-funcionalista das fontes deixadas por cronistas do Brasil Colonial. Dedicou ao assunto dois livros, um relativo à organização social da tribo, outro à função social da guerra entre esses mesmos índios. Por discutível que pareça, parte dos resultados [306] particulares a que chega pelo exame crítico dos textos - como, por exemplo, a interpretação da couvade Tupinambá ou a relação entre a antropofagia ritual e o "culto dos antepassados" - em nada afeta o mérito principal daquelas obras: o de fazerem compreender a realidade sociocultural Tupinambá com referência a categorias etnológicas e sociológicas que 
elevam a visão dos fenômenos acima e além do que proporcionam simples relatos etnográficos mais ou menos bem integrados. Embora não seja exclusiva em suas obras, predomina nelas a aplicação do método funcionalista.

Representante da etnologia a quem o conhecimento do índio interessa mais com referência à elaboração de teorias etnossociológicas do que inversamente é também Claude Lévi-Strauss, cujos trabalhos não se restringem a populações tribais extintas, nem procuram caracterizar, por meio de diferentes ângulos conjugados, determinada cultura tribal. Em geral, o autor seleciona, ao contrário, certas questões particulares, discutindo-as sempre de um ponto de vista específico. Se um dia Lévi-Strauss empreender a tarefa de integrar e sistematizar, refundindo-os em uma obra de conjunto, os resultados sobre culturas indígenas brasileiras assim obtidos, tanto a etnologia brasileira como a etnologia geral terão dado um grande passo para frente.

Dentre os setores mais negligenciados das investigações etnológicas referentes ao Brasil, é preciso destacar o da mitologia, cujo estudo progrediu pouco, em comparação, por exemplo, com o que se realizou no tocante às tribos indígenas norte-americanas. Com exceção de muitos artigos sobre questões particulares, como os de Métraux, e de alguns livros, como os de Ribeiro e Zerries, não há trabalhos interpretativos da mitologia de índios brasileiros que satisfaçam as exigências científicas modernas. Isso é tanto mais de se lamentar do que todas ou quase todas as teorias antropológicas postas em uso pelos cientistas das diferentes escolas, pois, por díspares que sejam, ofereceriam perspectivas promissoras para a exploração do material mitológico ora disponível. Ensaios funcionalistas, como [307] estudos de tipologia cultural, como ainda os que focalizam de preferência as relações entre cultura e personalidade ou, para dar mais exemplo, os de aculturação, sem mencionar os trabalhos puramente difusionistas, um tanto desacreditados hoje em dia, revelaram, em outras terras, a inesgotável riqueza de pontos de apoio que a mitologia oferece para a análise cultural.

O último e único trabalho em que se elabora uma sistematização teoricamente fundamentada da mitologia brasileira (ou melhor, sul-americana) é o de Ehrenreich, magistral em seu sentido e para a época, mas distante, na posição teórica e nas conclusões, do que hoje se esperaria de empreendimento dessa ordem. Diga-se de passagem, daqui a alguns meses, o volume de Ehrenreich poderá comemorar seu cinquentenário. E a única obra em que até hoje a mitologia de uma tribo brasileira foi explorada com êxito, parcialmente, embora para compreensão menos superficial de uma determinada cultura, isto é, da mentalidade, dos valores, da organização social e dos padrões de comportamento característicos de uma tribo, 
é a de Nimuendajú sobre os Apapokúva, que também já apareceu há quarenta anos. Não se deve esquecer, enfim, que sobre a geração anterior levamos a vantagem de possuirmos, no campo da mitologia, instrumento de trabalho tão valioso como o é a sistematização dos motivos etiológicos por Lehmann-Nitsche, que data de 1939.

Tanto mais se há de estranhar o atraso, quanto o material acumulado (embora colhido, sem dúvida, de maneira caótica e apenas à margem de pesquisas orientadas para outros objetivos) já seria mais que suficiente para que nele algum mitólogo experimentasse sua sagacidade. Ao lado de muitos textos de valor duvidoso, anotados ao acaso e sem respeito às exigências científicas, já possuímos coleções de mitos bastante volumosas (em parte talvez quase completas) de bom número de tribos, como a dos Xipáia, Karajá, Xerénte, Timbíra, Tenetehára, Kadiuéo, Umutína, Vapidiána, Taulipáng, Borôro e outras mais. Seria de se desejar, é bem verdade, que no futuro os pesquisadores fizessem o possível por publicarem [308] o repertório dos textos também no idioma original, de preferência com tradução interlinear, o que para os índios brasileiros até hoje se tem feito apenas esporadicamente. Dentre as louváveis exceções, quero mencionar os corpora mythorum de Koch-Grünberg e de Colbacchini e Albisetti, que nisso parecem ter seu maior valor.

Para se compreender a perda que também para os estudos linguísticos representa a não divulgação dos textos míticos no idioma original, lembro, de passagem, o que significam, como marcos decisivos no conjunto das publicações indianistas brasileiras, obras como Die Bakaïri-Sprache, de Karl von den Steinen, Rã-txa $h u-n i ́-k u-i ̈$, de Capistrano de Abreu, e o já mencionado volume sobre mitologia que integra o Vom Roroima zum Orinoco, de Theodor Koch-Guünberg. Poucos os trabalhos linguísticos destes últimos vinte e cinco anos - salvo talvez os de Jules Henry, Chrisostomus Strömer e Plínio Ayrosa - que se possam comparar àqueles três livros (ao primeiro, principalmente), pelo simples fato de os pesquisadores atuais não aproveitarem suficientemente os recursos modernos - inclusive técnicos - de levantamento linguístico por meio do registro da mitologia e de outros textos corridos. Minha experiência de campo me revelou ou, pelo menos, fez-me entrever as imensas possibilidades, que, a esse respeito, ofereceria, por exemplo, a análise comparativa dos mitos guarani nos três dialetos da tribo hoje falados no Brasil (sabe Deus por quanto tempo ainda), dialetos que, em virtude de certas características da religião, se conservaram em diferentes estratos, entre os quais uma linguagem notoriamente arcaica, perpetuada sobretudo pela relativa fixidez dos textos míticos e de uma série de cantos cerimoniais. Com referência, aliás, ao muito que resta por empreender na seara linguística - e que deve ser empreendido antes que seja tarde, de vez que a undécima hora se aproxima -, não há 
como silenciar, para apenas dar mais um exemplo, sobre o atraso em que andamos no estudo das línguas Jê, tanto do ponto de vista da análise sistemática e menos superficial da estrutura de um idioma qualquer dessa família, [309] quanto da comparação das línguas Jê entre si e destas com as do grupo Kaingang e outras, especialmente do Brasil oriental (na medida em que sobram representantes que os falam), idiomas outrora tidos sumariamente como Jê e desde a reclassificação de Loukotka encarados como conjunto de famílias independentes, com pouca ou nenhuma relação entre si. Creio ser ocioso insistir aqui na possibilidade de que não só os linguistas, mas também os etnólogos atuais encontrariam nessa ordem de cogitações para elucidar não somente questões linguísticas, como ainda a uns quantos aspectos obscuros da história racial e cultural do Brasil pré-cabralino.

Um dos progressos mais notáveis da etnologia brasileira destes últimos decênios é o incremento dos trabalhos monográficos sobre tribos de diferentes regiões do país. Em especial, cumpre mencionar os volumes de Nimuendajú sobre os Apinayé, os Xerénte, os Timbira orientais - todas tribos do grupo Jê - e o que trata dos Tukúna. São contribuições de peso, que vieram não apenas enriquecer o material, mas abrir perspectivas novas aos estudos indianistas. Mostrou muito bem Lévi-Strauss, em comunicação ao Congresso de Americanistas de Nova York, como em artigo posterior, publicado em 1952, com a verificação, que a economia dessas tribos não podem ser rotuladas sem mais nem menos de "coleta e caça", bem como a descoberta de estruturas sociais sobremodo complexas, caracterizadas por divisões dualistas concomitantes, recortando-se umas às outras, possibilitando, por exemplo, novas hipóteses, de particular interesse, sobre a noção de arcaísmo cultural aplicado a nossas tribos indígenas. Graças àquelas monografias, como à de Colbacchini e Albisetti, como, ainda, às investigações do próprio Lévi-Strauss entre os Nambikuára, o estudo do contravertido problema das metades ou classes exógamas pode ser aprofundado não somente para o caso particular dos índios do Brasil, mas também com vistas à sua formulação socioantropológica geral.

É verdade, como já se indicou, que nossa bibliografia etnológica se ressente da falta de monografias, por [310] assim dizer, completas ou multilaterais. Todavia, mais importante do que a pretensão de abranger em uma só apresentação monográfica o conjunto de todas as facetas importantes dessa ou daquela cultura é o estudo de certos aspectos ou problemas, bem delimitados e em profundidade mais do que em extensão. Ninguém ignora que na observância desse princípio jaz a força peculiar de grande parte dos trabalhos ingleses modernos sobre a antropologia social. São estudos em que a monografia é antes um meio do que um fim. 
Não nos esqueçamos de que o exaustivo das monografias tribais é ilusório, como a fata-morgana.

Inclino-me a admitir que a monografia de Wagley e Galvão sobre os Tenetehára teve a sua bem merecida repercussão precisamente por nela se conter uma visão global da cultura desses aborígenes com vistas a um objetivo teórico definido e bastante preciso: o de evidenciar, por meio da descrição, a uns tantos processos de transcrição ou fenômenos de aculturação. De mais a mais, é no setor dos estudos de aculturação, do qual não me ocuparei aqui, por ser objeto de outro symposium desse Congresso, que temos de registrar extraordinário avanço nestes últimos anos. Baldus foi o primeiro a dispensar à mudança cultural consequente aos contatos entre os índios e o mundo ocidental interesse não apenas esporádico, mas bastante sistemático. A meu ver, o ponto culminante, como contribuição de alcance teórico, nessa ordem de preocupações indianistas, na medida em que se referem ao Brasil, é o livro de Watson sobre os Kaiová de Taquapiri, pelo menos no exame da aculturação econômica. Mudanças de religião e de mitologia em face de contatos culturais foram analisadas por Darcy Ribeiro, em seu trabalho sobre os Kadiueo, mas já temos também bom número de exposições panorâmicas sobre a aculturação de uma ou outra tribo, como a de Altenfelder Silva sobre os Terêno, o artigo do Padre Saake sobre os Borôro, o de Caspar sobre os Tuparí. Cito-os para pôr em relevo o passo dado nesse domínio, um dos mais notáveis do período de que nos ocupamos aqui. O que [311] se requer agora são estudos mais intensivos, de profundidade, sobre a marcha aculturativa de determinada tribo ou de algumas tribos em confronto uma com a outra, para se porem a descoberto, digamos, a relação entre aculturação e personalidade e outros aspectos mais específicos. Como tarefa preparatória talvez fosse desejável a realização, no Brasil, de uma empresa de equipe à maneira da que há quase vinte anos se levou a cabo nos Estados Unidos, sob a direção de Linton, e que, ao lado da obra teórica de Herskovits sobre aculturação, foi a que mais impulsionou os trabalhos nesse setor entre os indianistas norte-americanos. Acho que um cientista experimentado, como Wagley - que me permita a amigável sugestão -, daria impulso extraordinário à nossa antropologia cultural, se assumisse a direção, por exemplo, de um trabalho de equipe que viesse a resultar em uma "aculturação em sete tribos índias do Brasil". Tenho por mim que não faltariam colaboradores.

Não fosse a limitação do tempo, muitos outros problemas poderiam e talvez devessem ser abordados aqui sob a alegação de serem fundamentais, como, por exemplo, o do mapa etnolinguístico, o dos estudos de psicologia étnica e dos métodos que requerem (testes, descrição de formas de comportamento em relação 
com a personalidade básica, etc.), o da caracterização tipológica das culturas, o da determinação de estratos culturais, o das sobrevivências indígenas nas culturas caboclas do Brasil atual, o das relações entre o desenvolvimento científico e os desejos ou propósitos de aplicação prática dos conhecimentos a problemas de administração e de aculturação dirigida, o das culturas históricas em relação com as pré-históricas, sobretudo no tocante ao que se deva esperar da exploração dos sambaquis e das demais jazidas arqueológicas. Seriam outras tantas possibilidades de mostrar - e outro não foi o objetivo desta palestra - o muito que resta por fazer.

Recebido para publicação em 06/12/13. Aceito para publicação em 10/12/13. 